\title{
-2548G > A LEP Polymorphism Is Positively Associated with Increased Leptin and Glucose Levels in Obese Saudi Patients Irrespective of Blood Pressure Status
}

\author{
Essa M. Sabi ${ }^{1}$ * , Lotfi S. Bin Dahman ${ }^{2,3} \mathbb{D}$, Abdul Khader Mohammed ${ }^{2,4}$, Khalid M. Sumaily ${ }^{1(D)}$ \\ and Nasser M. Al-Daghri ${ }^{2}$ (D) \\ 1 Clinical Biochemistry Unit, Pathology Department, College of Medicine, King Saud University, \\ Riyadh 11461, Saudi Arabia; ksumaily@ksu.edu.sa \\ 2 Chair for Biomarkers of Chronic Diseases, Department of Biochemistry, College of Science, \\ King Saud University, Riyadh 11451, Saudi Arabia; lotfydahman@hu.edu.ye (L.S.B.D.); \\ makhaderonline@gmail.com (A.K.M.); aldaghri2011@gmail.com (N.M.A.-D.) \\ 3 Department of Medical Biochemistry, College of Medicine and Health Sciences, Hadhramout University, \\ Mukalla 50511, Yemen \\ 4 Sharjah Institute for Medical Research, University of Sharjah, Sharjah 27272, United Arab Emirates \\ * Correspondence: esabi@ksu.edu.sa
}

check for

updates

Citation: Sabi, E.M.; Bin Dahman,

L.S.; Mohammed, A.K.; Sumaily,

K.M.; Al-Daghri, N.M. -2548G>A

LEP Polymorphism Is Positively

Associated with Increased Leptin and

Glucose Levels in Obese Saudi

Patients Irrespective of Blood

Pressure Status. Medicina 2022, 58,

346. https://doi.org/10.3390/

medicina58030346

Academic Editor: Domenico Serg

Received: 12 January 2022

Accepted: 22 February 2022

Published: 24 February 2022

Publisher's Note: MDPI stays neutral with regard to jurisdictional claims in published maps and institutional affiliations.

Copyright: () 2022 by the authors Licensee MDPI, Basel, Switzerland. This article is an open access article distributed under the terms and conditions of the Creative Commons Attribution (CC BY) license (https:// creativecommons.org/licenses/by/ $4.0 /)$.

\begin{abstract}
Background and Objectives: In this study, we aimed to investigate the link between common -2548G > A (rs7799039) promoter variant of the human leptin gene (LEP) with leptin and serum glucose leptin levels in obese Saudi patients. Materials and Methods: A total of 206 Saudi adults (80 obese normotensive nondiabetics, 76 obese hypertensive with Type 2 Diabetes and 50 normotensive nondiabetic controls) were genotyped for -2548G >A LEP polymorphism using the polymerase chain reaction-restriction fragment-length polymorphism technique. Results: Participants with minor AA genotype had significantly higher blood glucose levels $(6.8 \pm 0.55 \mathrm{mmol} / \mathrm{L}$ vs. $5.8 \pm 0.30 \mathrm{mmol} / \mathrm{L}$; $p<0.04)$ and HOMA-IR ( $4.1 \pm 0.84$ vs. $2.6 \pm 0.67 ; p=0.03)$ against those carrying major GG genotype. Participants with heterozygous GA genotype had significantly higher serum leptin levels against those carrying major GG genotype $(40.0 \pm 2.6 \mathrm{ng} / \mathrm{mL}$ vs. $29.6 \pm 2.6 \mathrm{ng} / \mathrm{mL} ; p=0.04)$. Further investigation showed that individuals with AA, GA, GA + AA genotypes are at greater risk of developing hyperglycemia compared to those with GG genotype [OR 3.7(1.6-8.4), $p=0.001 ; 3.2(1.2-8.6), p=0.03$; 3.5 (1.6-7.7), $p=0.001$, respectively]. Additionally, the -2548AA allele was shown to be a risk factor for hyperglycemia [OR $1.9(1.2-3.0), p=0.006]$. Our data revealed no relationship between this variant of the LEP gene with systolic and diastolic BP, signifying that this genetic variant is not a significant marker of obesity and hypertension in the Saudi population. Conclusions: AA and GA genotypes and LEP gene -2548AA alleles may signify potent risk factors predisposing healthy individuals to develop T2DM regardless of blood-pressure profile.
\end{abstract}

Keywords: leptin; leptin gene polymorphism; obesity; hypertension; type 2 diabetes; Saudi Arabia

\section{Introduction}

Obesity is associated with diabetes mellitus (T2DM), cardiovascular disease and hypertension, and is one of the most serious health problems of the last century [1,2]. Most patients with hypertension suffer from an increased body mass index (BMI) [3], along with 7.6 million early deaths being attributed to hypertension [4]. The prevalence of obesity and hypertension in Saudi Arabia is 35\% and 30.2\%, correspondingly [5,6]. Even though the link between blood pressure and increased body mass has been reported $[7,8]$ these associations are not entirely understood [9].

Leptin (16-kDa protein) is comprised of 164 amino acids and is predominantly produced by white adipose tissue. Leptin plays an important role in regulating body weight 
by preventing food intake and stimulating energy expenditure [10]. Furthermore, leptin appears to play a role in the development of hypertension. As a result, leptin-mediated sympathetic activation carried in the circulatory system and at the renal stage could potentially impact BP management and lead to obesity-related hypertension [11,12].

The leptin $(L E P)$ gene located at chromosomal location $7 \mathrm{q} 31.3$ includes three introns and three exons, spanning approximately $18 \mathrm{~kb}[13,14]$. A common variant of the -2548G $>\mathrm{A}$ (rs7799039) leptin promoter results in the transition substitution of guanine to adenine at nucleotide position -2548 upstream of the ATG start site [15]. This variant has previously been reported to be association with elevated serum leptin levels, metabolic syndrome, hypertension and obesity [16-22]. On the other hand, there is conflicting information relating to these associations with some studies reporting a positive correlation and some reporting a negative correlation. Therefore, this study aimed to investigate the link between the $-2548 \mathrm{G}>\mathrm{A}$ LEP polymorphism with elevated serum glucose and leptin levels in obese Saudi patients.

\section{Subjects and Methods}

\subsection{Subjects}

A total of 206 Saudi adults aged $\geq 35$ years old (112 females and 94 males) were randomly recruited from seventeen thousand consenting Saudi subjects in the RIYADH COHORT -Biomarker Screening in Riyadh Project. The study subjects were subdivided into 80 obese normotensive nondiabetics (ND), 50 normotensive nondiabetic (ND) controls, and 76 obese hypertensives with T2DM. Patients were informed of the study protocol, and were asked for their informed consent. To scrutinize the genetic cause of the patients, the exclusion criteria considered were as follows: regular use of antihypertensive drugs, chronic liver disease, kidney disease, cardiovascular problems, cancers and patients with acute comorbidities that required immediate medical attentions. The Declaration of Helsinki was followed and the present study was approved by the ethical committee at King Saud Medical City, Ministry of Health, Kingdom of Saudi Arabia on 17-1-2012 with reference number 11395.

\subsection{Anthropometric and Blood Pressure Measurements}

According to the World health organization (WHO) standard, anthropometric measurements obtained from all participants include weight $(\mathrm{kg})$, height $(\mathrm{cm})$, waist $(\mathrm{cm})$, hips $(\mathrm{cm})$, and hip circumference ratio (WHR) [23]. The Holtain Khan abdominal caliper from Holtain Ltd. (Crymych, UK) measured the sagittal abdominal diameter as previously reported by Al-Daghri et al. [24]. The standard equation of weight in kilogram/height in centimeter $\left(\mathrm{kg} / \mathrm{m}^{2}\right)$ was used to calculate body mass index (BMI). Obese subjects were defined as BMI $\geq 30 \mathrm{~kg} / \mathrm{m}^{2}$ and normal weight subjects were identified via a BMI of 18-25, according to WHO guidelines. Patients with systolic blood pressure $\geq 140 \mathrm{mmHg}$ and diastolic blood pressure $\geq 90 \mathrm{mmHg}$ were defined as having hypertension [25]. Diabetic patients were diagnosed based on medical history, regular anti-diabetic medications, or the American Diabetes Association (ADA) criteria [26]. Patients with T2DM were defined as fasting blood glucose level $\geq 7.1 \mathrm{mmol} / \mathrm{L}, 2 \mathrm{~h}$ postprandial plasma glucose level $\geq 11.1 \mathrm{mmol} / \mathrm{L}$ ) [26]

\subsection{Blood Sampling and Biochemical Analyses}

Whole blood $(10 \mathrm{~mL})$ was collected from all participants, after overnight fasting, by vein puncture in tubes with EDTA for genomic DNA extraction. The collected blood samples were immediately transported to the laboratory. Separation of serum was performed and was stored at $-20^{\circ} \mathrm{C}$ for biochemical analyses. A chemical analyzer was employed to determine blood glucose, triglycerides, total cholesterol and High density lipoprotein (HDL) cholesterol (Konelab, Finland). Friedwald's formula was used to measure Low density lipoprotein (LDL) cholesterol concentrations [27]. Serum leptin and insulin levels were analyzed using Luminex Milliplex kits (Luminexcorp, Austin, TX, USA). Insulin sensitivity was assessed by the homeostasis model assessment of insulin resistance (HOMA- 
IR), calculated using the following formulae: fasting insulin (IU/mL) $X$ fasting glucose $(\mathrm{mmol} / \mathrm{L}) / 22.5$ [28]. All biochemical assays were carried out using duplicates and the average obtained from two values was considered for data analyses. Duplicate samples that failed to provide a coefficient of variation of $<15 \%$ were re-analyzed. The intra-assay and inter-assay coefficients of variation (CV) for serum leptin was $(7.9 \%$ and $15 \%)$ and insulin $(5.1 \%$ and $14 \%)$, respectively.

\subsection{Genetic Analyses of LEP G-2548A Polymorphism}

Blood DNA was extraction was performed using a Blood genomic mini spin kit (GE Health Care, UK). At the same time, the concentration and purity of the DNA were determined using the Nanodrop spectrophotometer. The -2548G>A LEP polymorphism (rs7799039) was analyzed using Polymerase chain reaction-restriction enzyme length polymorphism (PCR-RFLP). A PCR mix (Taq ready mix, Kapa Biosystems, Wilmington, MA, USA) and the following primers: 5'AAAGCAAAGACAGGCATA AAAA-3' (antisense) and $5^{\prime}$-TTTCCTGTAATTTTC CCGTGAG-3' (sense), were employed for the amplification of the 242bp DNA fragment. Conditions for PCR were set as mentioned by Mammés et al. [10]. The PCR reaction in the final reaction volume of $50 \mu \mathrm{L}$ contained genomic DNA (50 ng), $0.4 \mu \mathrm{M}$ of primer (sense and antisense) and KAPA Taq ready mix $(25 \mu \mathrm{L})$ DNA polymerase. PCR condition was as following: initial denaturation of $5 \mathrm{~min}$ at $95^{\circ} \mathrm{C}$ followed by 35 cycles with each cycle containing denaturation at for $15 \mathrm{~s}$ at $94{ }^{\circ} \mathrm{C}, 30 \mathrm{~s}$ at $52{ }^{\circ} \mathrm{C}$ (annealing), $30 \mathrm{~s}$ at $72{ }^{\circ} \mathrm{C}$ (extension), and followed by final extension for $5 \mathrm{~min}$ at $72{ }^{\circ} \mathrm{C}$. The amplified DNA products were digested for $2 \mathrm{~h}$ at $37^{\circ} \mathrm{C}$ with $2 \mathrm{U}$ of $\mathrm{HhaI}$ restriction enzyme further separated on $2.5 \%$ agarose gels with stain (ethidium bromide). The $242 \mathrm{bp}$ PCR product (AA) was digested into $181 \mathrm{bp}$ (GG) and $61 \mathrm{bp}$ (GA) fragments in the presence of a $\mathrm{G}$ nucleotide (polymorphic variant) but not in its absence.

\subsection{Statistical Analysis}

The mean and standard deviation (SD) were used to express the data. The parameters of the analyzed groups were compared using an analysis of covariance (ANCOVA). Analysis of covariance (ANCOVA) was performed, adjusting for the potential confounder of age. Odds ratios (OR) and 95\% confidence intervals were measured by logistic regression (multinomial) for the allele and genotype frequencies of -2548G $>$ A LEP polymorphism. Data were analyzed using the Statistical Package for the Social Sciences for Windows (SPSS ver16.0). $A p$-value of $<0.05$ was considered statistically significant.

\section{Results}

\subsection{Anthropometric and Biochemical Characteristics of Participants}

Biochemical and anthropometric characteristics of the participants are represented in Table 1. There was no significant difference for the mean age of the study groups $(p=0.14)$ as shown in Table 1. Obese hypertensive with T2D and obese normotensive ND patients had significantly higher systolic BP $(p=0.01, p<0.001)$, diastolic $\mathrm{BP}(p=0.002$, $p<0.001)$, BMI $(p<0.001, p<0.001)$, waist $(p<0.001, p<0.001)$, hips $(p=0.001, p<0.001)$ and SAD $(p<0.001, p<0.001)$, respectively matched with normotensive ND controls. Obese hypertensive with T2D patients had significantly higher levels of HDL-cholesterol $(p=0.04)$ than the obese normotensive ND. Obese hypertensive with T2D patients had significantly higher serum glucose levels $(p=0.009)$ than normotensive ND controls and obese normotensive ND. Further, Obese normotensive ND and obese hypertensive with T2D patients had elevated serum leptin levels $(p<0.001, p<0.001)$ and HOMA-IR $(p=0.01)$ when compared with normotensive ND controls, while no significant difference in serum total cholesterol $(p=0.60)$, LDL-cholesterol $(p=0.99)$, triglycerides $(p=0.08)$, and insulin $(p=0.15)$ was observed. 
Table 1. Anthropometric and clinical characteristics of the study population.

\begin{tabular}{|c|c|c|c|c|}
\hline Parameter & Normotensive ND Control & $\begin{array}{c}\text { Obese Normotensive } \\
\text { Nondiabetics (ND) }\end{array}$ & $\begin{array}{c}\text { Obese Hypertensives } \\
\text { with T2D }\end{array}$ & $p$-Value \\
\hline $\mathrm{N}$ & 50 & 80 & 76 & \\
\hline Age & $47.9 \pm 5.4$ & $47.7 \pm 6.0$ & $49.4 \pm 5.9$ & 0.14 \\
\hline Gender $(\mathrm{M} \backslash \mathrm{F})$ & $(32 / 18)$ & $(37 / 43)$ & $(25 / 51)$ & 0.003 \\
\hline $\mathrm{BMI}\left(\mathrm{kg} / \mathrm{m}^{2}\right)$ & $22.9 \pm 2.1$ & $34.1 \pm 4.2 *$ & $35.1 \pm 4.7^{*}$ & $<0.001$ \\
\hline Waist (cm) & $84.7 \pm 14.6$ & $99.1 \pm 16.6^{*}$ & $99.1 \pm 20.3^{*}$ & $<0.001$ \\
\hline Hips (cm) & $96.5 \pm 17.1$ & $110.4 \pm 19.6^{*}$ & $111.3 \pm 24.0^{*}$ & $<0.001$ \\
\hline $\mathrm{SAD}(\mathrm{cm})$ & $19.6 \pm 4.0$ & $24.9 \pm 5.5^{*}$ & $25.5 \pm 4.1^{*}$ & $<0.001$ \\
\hline Systolic BP (mmHg) & $116.7 \pm 8.6$ & $121.9 \pm 10.4$ * & $144.1 \pm 11.2^{*,+}$ & $<0.001$ \\
\hline Diastolic BP (mmHg) & $75.3 \pm 5.6$ & $78.8 \pm 6.2^{*}$ & $91.2 \pm 4.0 *,+$ & $<0.001$ \\
\hline Leptin (ng/mL) & $15.6 \pm 5.2$ & $38.8 \pm 6.2 *$ & $38.6 \pm 5.1^{*}$ & $<0.001$ \\
\hline HDL (mmol/L) & $0.83 \pm 0.30$ & $0.74 \pm 0.31$ & $0.86 \pm 0.32{ }^{\dagger}$ & 0.04 \\
\hline $\mathrm{TC}(\mathrm{mmol} / \mathrm{L})$ & $5.3 \pm 1.1$ & $5.4 \pm 1.2$ & $5.5 \pm 1.1$ & 0.59 \\
\hline $\mathrm{LDL}(\mathrm{mmol} / \mathrm{L})$ & $3.8 \pm 1.0$ & $3.8 \pm 1.1$ & $3.8 \pm 1.0$ & 0.99 \\
\hline $\mathrm{TG}(\mathrm{mmol} / \mathrm{L})$ & $1.5 \pm 0.24$ & $1.8 \pm 0.39$ & $1.8 \pm 0.35$ & 0.08 \\
\hline FBG (mmol/L) & $5.8 \pm 2.0$ & $6.4 \pm 2.3$ & $7.2 \pm 3.1 *$ & 0.01 \\
\hline Insulin (IU/mL) & $9.4 \pm 2.5$ & $11.4 \pm 1.2$ & $12.3 \pm 1.2$ & 0.15 \\
\hline HOMA-IR & $2.4 \pm 0.85$ & $3.1 \pm 0.64$ * & $3.8 \pm 0.72 *$ & 0.01 \\
\hline & \multicolumn{4}{|c|}{$\begin{array}{l}\text { Level of significance at } p<0.05 \text {; * represents group } 2 \text { and } 3 \text { is significantly different normotensive ND control, } \\
t \text { represents group } 3 \text { is significantly different obese normotensive ND. Analysis of covariance (ANCOVA) is } \\
\text { done; age was set as a covariance. ND: non-diabetes; T2D: type two diabetes; SAD: sagittal abdominal diameter; } \\
\text { BMI: body mass index; diastolic BP: diastolic blood pressure; systolic BP: systolic blood pressure; TC: total choles- } \\
\text { terol; HDL: high-density lipoprotein; LDL: low-density lipoprotein; TG: triglyceride; HOMA-IR: homeostasis } \\
\text { model assessment of insulin resistance; FBG: fasting blood glucose. All data is represented by mean } \pm \text { standard } \\
\text { deviation (SD). }\end{array}$} \\
\hline
\end{tabular}

\subsection{Distribution of Alleles and Genotype Frequency for -2548G>A LEP Polymorphism}

PCR RFLP analysis of the $-2548 \mathrm{G}>\mathrm{A}$ LEP provided three different variants of the genotype, namely GA heterozygous, GG for the wild type and AA for the homozygous (mutant type). For controls-normotensive ND, the genotype frequencies of the $-2548 \mathrm{G}>\mathrm{A}$ LEP polymorphism were $40.0 \%$ (GA), $46.0 \%$ (GG) and $14.0 \%$ (AA). With regard to obese normotensive ND, individuals with GA, GG, and AA genotypes were $38.8 \%, 40.0 \%$, and $21.2 \%$, respectively. Furthermore, obese hypertensive T2D patients had GA, GG and AA frequencies of $48.7 \%, 33.0 \%$, and $18.3 \%$, respectively (Table 2). Furthermore, the -2548GG allele was $66 \%$ in normotensive ND controls. Additionally, $59.4 \%$ of the $-2548 \mathrm{G}$ allele was found in obese normotensive ND and $57.2 \%$ in obese hypertensive with T2D patients. The -2548AA allele frequencies were $34.0 \%$ in normotensive ND controls, obese normotensive ND patients had $40.6 \%$, and obese hypertensive T2D patients had $42.8 \%$ (Table 2). Additionally, the relationship between metabolic disorders (BMI, diabetes, and hypertension) and the $-2548 \mathrm{G}>\mathrm{A}$ LEP polymorphism is presented in Table 2 . We found no significant difference in allele or genotype frequencies between obese hypertensive T2D compared to normotensive ND controls. 
Table 2. Genotype and alleles frequency distribution of the -2548G/A LEP polymorphism.

\begin{tabular}{|c|c|c|c|c|c|c|c|}
\hline & Normotensive & \multicolumn{3}{|c|}{ Obese Normotensive } & \multicolumn{3}{|c|}{ Obese Hypertensive } \\
\hline & ND Control & \multicolumn{3}{|c|}{ ND } & \multicolumn{3}{|c|}{ T2D } \\
\hline & $\mathrm{N}($ in \%) & & $\begin{array}{l}\text { Odds ratio } \\
(95 \% \mathrm{CI})\end{array}$ & $p$-value & $\mathrm{N}($ in $\%)$ & $\begin{array}{l}\text { Odds ratio } \\
(95 \% \mathrm{CI})\end{array}$ & $p$-value \\
\hline \multicolumn{8}{|c|}{ Genotype frequency } \\
\hline GG & $23(46.0)$ & $32(40.0)$ & \multicolumn{2}{|c|}{1} & $25(33.0)$ & \multicolumn{2}{|c|}{1} \\
\hline GA & $20(40.0)$ & $31(38.8)$ & $1.1(0.51-2.4)$ & 0.84 & $37(48.7)$ & $1.7(0.77-3.7)$ & 0.23 \\
\hline AA & $7(14.0)$ & $17(21.2)$ & $1.7(0.62-4.8)$ & 0.32 & $14(18.3)$ & $1.8(0.63-5.3)$ & 0.30 \\
\hline $\mathrm{GA}+\mathrm{AA}$ & $27(64.0)$ & $48(60.0)$ & $1.3(0.62-2.6)$ & 0.58 & $51(67.0)$ & $1.0(0.49-2.1)$ & 0.90 \\
\hline \multicolumn{8}{|c|}{ Allele frequency } \\
\hline G allele & $66(66.0)$ & $95(59.4)$ & 1 & & $87(57.2)$ & 1 & \\
\hline A allele & $34(34.0)$ & $65(40.6)$ & $1.3(0.78-2.2)$ & 0.29 & $65(42.8)$ & $1.4(0.85-2.4)$ & 0.18 \\
\hline
\end{tabular}

Data are represented as $\mathrm{n}(\%)$. Significant difference from homozygous GG. ND: non-diabetic; T2D: type two diabetes. GG, GA and AA are genotypes.

\subsection{Anthropometric and Clinical Characteristics of the Study Population}

The characteristics of the anthropometric and biochemical parameters with respect to the $-2548 \mathrm{G}>\mathrm{A}$ LEP polymorphism are presented in Table 3 . There was no significant association between the genotypes of the $-2548 \mathrm{G}>\mathrm{A}$ LEP polymorphism with systolic $\mathrm{BP}$, diastolic BP, BMI, hips and waist. In the study group, AA genotype carriers were significantly associated with increased blood glucose levels $(p<0.04)$ and HOMA-IR $(p=0.03)$. In contrast, the GA genotype was significantly associated with increased serum leptin levels $(p=0.04)$. Additionally, in normotensive ND controls, the GA genotype was significantly associated with increased leptin levels $(p=0.04)$. In contrast, no significant association between the genotypes of this gene and serum total cholesterol, HDL-cholesterol, LDL-cholesterol, triglyceride, and insulin were observed (Table 3).

Further analysis showed that the individuals carrying GA, AA, GA + AA genotypes were more susceptible to the development of hyperglycemia matched to those carrying the GG genotype [OR 3.7 (1.6-8.4), $p=0.001 ; 3.2(1.2-8.6), p=0.03 ; 3.5$ (1.6-7.7), $p=0.001$, respectively] (Figure 1). Additionally, the -2548A A allele was found to be a risk factor of diabetes in individuals with hyperglycemia [OR $1.9(1.2-3.0), p=0.006$ ] (Figure 1). However, no such association was found between hypertension and hyperleptinemia.

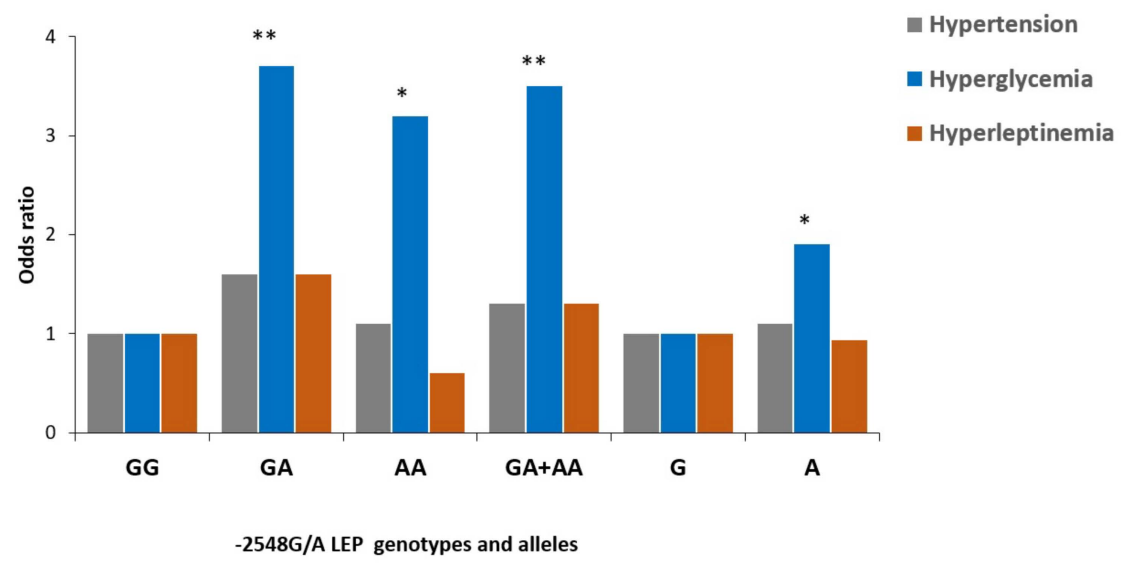

Figure 1. Genotypes and alleles distribution of the -2548G/A LEP polymorphism in individuals with normal vs. elevated blood pressure (blood pressure $\geq 140 / 90$ ) and normal vs. elevated blood glucose $(\geq 7.0 \mathrm{mmol} / \mathrm{L})$ participants; as well as normal vs. hyperleptinemia Subjects $(9 \mathrm{ng} / \mathrm{mL}$ males and $27 \mathrm{ng} / \mathrm{mL}$ ). GG is considered as a reference genotype. $\mathrm{G}$ allele is considered as a reference allele * denotes $p<0.05,{ }^{* *}$ denotes $p<0.005$. 
Table 3. Anthropometric and clinical characteristics of the study population with respect to the -2548G/A LEP polymorphism.

\begin{tabular}{|c|c|c|c|c|c|c|c|c|c|c|c|c|}
\hline & \multicolumn{3}{|c|}{ Overall } & \multicolumn{3}{|c|}{$\begin{array}{l}\text { Normotensive ND } \\
\text { Healthy Control Group }\end{array}$} & \multicolumn{3}{|c|}{$\begin{array}{l}\text { Obese Normotensive } \\
\text { ND Group }\end{array}$} & \multicolumn{3}{|c|}{$\begin{array}{l}\text { Obese Hypertensive } \\
\text { T2D Group }\end{array}$} \\
\hline & GG & GA & AA & GG & GA & AA & GG & GA & AA & GG & GA & AA \\
\hline $\mathrm{N}$ & 80 & 88 & 38 & 23 & 20 & 7 & 32 & 31 & 17 & 25 & 37 & 14 \\
\hline Age & $48.4 \pm 6.0$ & $48.6 \pm 5.8$ & $47.9 \pm 5.6$ & $48.2 \pm 5.7$ & $46.9 \pm 5.2$ & $49.8 \pm 5.3$ & $48.5 \pm 5.7$ & $47.4 \pm 6.1$ & $46.7 \pm 6.4$ & $48.5 \pm 7.0$ & $50.4 \pm 5.6$ & $48.4 \pm 4.8$ \\
\hline Gender (M/F) & $(39 / 41)$ & $(34 / 54)$ & $(21 / 17)$ & $(15 / 8)$ & $(12 / 8)$ & $(5 / 2)$ & $(17 / 15)$ & $(10 / 21)$ & $(10 / 7)$ & $(7 / 18)$ & $(12 / 25)$ & $(6 / 8)$ \\
\hline BMI $\left(\mathrm{kg} / \mathrm{m}^{2}\right)$ & $31.6 \pm 6.7$ & $32.2 \pm 6.4$ & $31.5 \pm 6.1$ & $23.2 \pm 2.6$ & $23.0 \pm 1.2$ & $21.7 \pm 1.4$ & $33.9 \pm 5.1$ & $34.9 \pm 4.0$ & $32.6 \pm 2.5$ & $35.6 \pm 4.1$ & $34.8 \pm 4.8$ & $35.1 \pm 5.3$ \\
\hline Waist (cm) & $97.1 \pm 17.7$ & $94.9 \pm 18.8$ & $93.3 \pm 20.4$ & $87.5 \pm 9.6$ & $83.8 \pm 10.8$ & $78.1 \pm 11.6$ & $100.1 \pm 16.3$ & $97.5 \pm 19.8$ & $100.4 \pm 10.2$ & $102.2 \pm 21.9$ & $98.9 \pm 19.4$ & $94.1 \pm 20.2$ \\
\hline Hips (cm) & $109.2 \pm 20.3$ & $106.6 \pm 22.5$ & $104.7 \pm 23.1$ & $97.8 \pm 9.3$ & $100.1 \pm 16.2$ & $80.1 \pm 11.0$ & $110.4 \pm 19.6$ & $109.1 \pm 22.8$ & $100.1 \pm 10.2$ & $118.1 \pm 24.0$ & $107.9 \pm 24.6$ & $107.5 \pm 21.8$ \\
\hline $\mathrm{SAD}(\mathrm{cm})$ & $23.3 \pm 4.7$ & $24.6 \pm 5.4$ & $22.6 \pm 2.7$ & $19.9 \pm 3.9$ & $19.8 \pm 4.2$ & $18.4 \pm 4.4$ & $23.8 \pm 5.0$ & $26.3 \pm 5.3$ & $23.4 \pm 7.1$ & $26.1 \pm 2.8$ & $25.6 \pm 4.6$ & $24.2 \pm 4.5$ \\
\hline $\begin{array}{c}\text { Systolic BP } \\
\text { (mmHg) }\end{array}$ & $127.5 \pm 16.1$ & $130.2 \pm 16.8$ & $128.4 \pm 12.1$ & $114.8 \pm 8.4$ & $117.5 \pm 9.0$ & $120.7 \pm 7.3$ & $121.8 \pm 9.8$ & $122.3 \pm 12.5$ & $121.5 \pm 7.4$ & $146.5 \pm 8.9$ & $143.8 \pm 13.3$ & $140.7 \pm 8.0$ \\
\hline $\begin{array}{l}\text { Diastolic BP } \\
(\mathrm{mmHg})\end{array}$ & $81.7 \pm 8.6$ & $83.1 \pm 9.4$ & $82.7 \pm 6.6$ & $74.9 \pm 8.5$ & $75.0 \pm 6.1$ & $77.1 \pm 3.9$ & $78.9 \pm 6.1$ & $78.4 \pm 6.9$ & $79.4 \pm 5.2$ & $91.6 \pm 3.4$ & $91.6 \pm 5.0$ & $89.6 \pm 2.0$ \\
\hline $\mathrm{TC}(\mathrm{mmol} / \mathrm{L})$ & $5.4 \pm 1.3$ & $5.5 \pm 1.0$ & $5.3 \pm 1.1$ & $5.3 \pm 1.2$ & $5.2 \pm 0.90$ & $5.9 \pm 1.2$ & $5.6 \pm 1.4$ & $5.4 \pm 1.0$ & $5.1 \pm 1.0$ & $5.3 \pm 1.2$ & $5.8 \pm 1.1$ & $5.4 \pm 1.0$ \\
\hline TG $(\mathrm{mmol} / \mathrm{L})$ & $1.82 \pm 0.10$ & $1.85 \pm 0.11$ & $1.86 \pm 0.21$ & $1.6 \pm 0.17$ & $1.4 \pm 0.10$ & $1.5 \pm 0.26$ & $2.0 \pm 1.0$ & $1.8 \pm 1.1$ & $2.1 \pm 1.8$ & $1.8 \pm 0.20$ & $2.1 \pm 0.20$ & $1.7 \pm 0.15$ \\
\hline $\mathrm{HDL}(\mathrm{mmol} / \mathrm{L})$ & $0.75 \pm 0.17$ & $0.81 \pm 0.17$ & $0.74 \pm 0.22$ & $0.75 \pm 0.18$ & $0.86 \pm 0.13$ & $0.80 \pm 0.24$ & $0.73 \pm 0.17$ & $0.75 \pm 0.18$ & $0.57 \pm 0.17$ & $0.76 \pm 0.16$ & $0.83 \pm 0.17$ & $0.96 \pm 0.20$ \\
\hline LDL (mmol/L) & $3.8 \pm 1.0$ & $3.8 \pm 0.99$ & $3.7 \pm 0.99$ & $3.7 \pm 1.1$ & $3.6 \pm 0.75$ & $4.3 \pm 0.81$ & $3.9 \pm 1.2$ & $3.7 \pm 1.0$ & $3.5 \pm 1.1$ & $3.6 \pm 0.20$ & $4.0 \pm 1.0$ & $3.5 \pm 1.0$ \\
\hline FBG $(\mathrm{mmol} / \mathrm{L})$ & $5.8 \pm 0.30$ & $6.6 \pm 0.50$ & $6.8 \pm 0.55 *$ & $5.8 \pm 0.16$ & $5.1 \pm 0.20$ & $7.1 \pm 0.76$ & $5.6 \pm 0.29$ & $6.8 \pm 0.48$ & $6.3 \pm 0.38$ & $6.1 \pm 0.37$ & $7.3 \pm 0.55$ & $7.6 \pm 0.61$ \\
\hline Insulin (IU/mL) & $10.2 \pm 1.2$ & $11.2 \pm 1.3$ & $13.0 \pm 1.2$ & $8.2 \pm 1.8$ & $9.4 \pm 1.6$ & $13.2 \pm 1.7$ & $11.0 \pm 1.1$ & $10.6 \pm 1.1$ & $13.0 \pm 1.2$ & $11.1 \pm 1.0$ & $12.8 \pm 1.1$ & $12.8 \pm 1.0$ \\
\hline HOMA-IR & $2.6 \pm 0.67$ & $3.3 \pm 0.73$ & $4.1 \pm 0.84^{*}$ & $2.2 \pm 0.88$ & $2.2 \pm 0.80$ & $3.8 \pm 0.88$ & $2.7 \pm 0.54$ & $3.2 \pm 0.68$ & $3.7 \pm 0.75$ & $3.0 \pm 0.62$ & $4.1 \pm 0.68$ & $4.5 \pm 0.95$ \\
\hline
\end{tabular}

Data represented by mean \pm standard deviation. Level of significance at $p<0.05 ;$ * represents group is significantly different from Homozygous GG. ND: non-diabetes; T2D: type two diabetes; SAD: sagittal abdominal diameter; diastolic BP: diastolic blood pressure; systolic BP: systolic blood pressure; TC: total cholesterol; TG: triglyceride; HDL: high-density lipoprotein; LDL: low -density lipoprotein; FBG: fasting blood glucose; HOMA-IR: homeostasis model assessment of insulin resistance and BMI: body mass index. 


\section{Discussion}

Previously, LEP was sequenced and analyzed for variants that are potentially associated with the pathophysiology of obesity and obesity-related complications such as T2DM and hypertension. One of these common polymorphisms is -2548G $>$ A with studies reported polymorphism to be associated with BMI among overweight Europeans [10], Tunisian volunteers [29]. Additionally, other studies show the link between obesity and the variant of the $-2548 \mathrm{G}>\mathrm{A} \operatorname{LEP}[19,30,31]$. However, there is conflicting evidence amongst different ethnicities for associations with BMI and obesity. Wang et al. found that individuals with a higher BMI had a significantly higher GG (wild-type, reference sequence) genotype than those with GA or AA genotypes in the Taiwanese aboriginal community [20]. Similarly, researchers from Tunisia [18], Turkey [32], and Romania [33] reported no association between the -2548G>A LEP polymorphism and higher BMI. Furthermore, other studies also have described no association between the -2548G $>$ A LEP polymorphism and obesity in Serbian [34], Spanish [35], Romanian [36], and Turkish obese patients [37].

In our study, there was a significant difference in the allelic distribution of patients compared with the healthy controls, having a probable effect on the risk of diabetes. The present study showed no association between this variant of the LEP gene with BMI, WHR, SAD, systolic and diastolic BP, indicating that this genetic variant is not a significant marker of hypertension and obesity in the Saudi population. Thus, we suggest that other potential contributing factors such as lifestyle, physical activity, ethnicity, nutritional and environmental factors may affect energy homeostasis. Thus, the GA and AA genotype carriers may present a chance to develop hyperglycemia compared to those with the GG genotype. Additionally, the -2548A allele was identified as a risk factor of diabetes in individuals with hyperglycemia against those carrying the $-2548 \mathrm{G}$ allele. The study also indicates that the GA genotype carriers had a significant association with increased leptin and serum levels.

Since the variant of $-2548 \mathrm{G}>\mathrm{A}$ LEP is located at the $5^{\prime}$ end in the promoter region, Gong et al. suggested this variant may effect $L E P$ gene expression and secretion via adipose tissue [38]. Moreover, the -2548G >A LEP polymorphism is close to the Sp1 transcriptionfactor binding site and two repetitive sequences of MER11 and Alu, regulating LEP transcription [39]. Furthermore, another study reported that the Sp1 binding site has a potent role in the transcriptional activation of the LEP promoter by insulin-mediated glucose metabolism [40]. However, the potential effects of the -2548G >A LEP polymorphism on leptin secretion and expression are still conflicting. For example, Tunisian obese individuals with the -2548AA allele had lower plasma leptin levels than those carrying the -2548GG allele [18]. On the other hand, Yiannakouris et al. [41] reported a significant association between the -2548GG allele and elevated serum leptin levels in Greek healthy individuals.

Additionally, the relationship among the $-2548 \mathrm{G}$ variant and increased serum leptin levels was reported in European [34], Brazilian [19], and Romanian obese individuals [25]. The AA genotype of -2548G >A LEP, on the other hand, was linked to higher serum leptin levels in the French men cohort study [10]. A Swedish study confirmed this finding, reporting that the -2548A allele was linked with elevated messenger RNA (mRNA) levels and adipose tissue leptin secretion rate [17]. In our study findings, only obese individuals with the GA genotype had increased leptin serum levels compared to those with the GG genotype. Based on the above findings, these conflicting results could arise from the presence of the -2548G $>$ A LEP polymorphism and other polymorphisms in leptin and leptin gene receptors, which were not assessed as part of this study. As previously identified in other studies showing different results from diverse backgrounds, the ethnicity and characteristics of Saudi individuals could also account for the conflicting findings. Additionally, sample size is a limitation of this study, and this may account for the conflicting results identified in this study. In addition, the study described herein did not measure HbA1c and adiponectin as metabolic markers of obesity and obesity-related complications.

Leptin suppresses glucose-stimulated insulin secretion and receptors of leptin on $\beta$ cells and fat cells, allowing it to control insulin secretion and action, or both [42]. Our 
study found that the AA genotype of $-2548 \mathrm{G}>\mathrm{A}$ LEP polymorphism was significantly associated with elevated blood glucose levels and HOMA-IR. Our results agree with data from Vaškù et al. [43], who suggested that the AA and AG genotype carriers have a significantly higher risk for gestational diabetes mellitus than those carrying the GG genotype. Additionally, a recent study in the North Indian population identified the rs7799039 AA genotype as a risk factor for T2DM [44]. However, these findings contradict those of a recent study, which found that carriers of the -2548GG allele were linked to higher blood glucose levels in T2DM patients [45]. Thus, based on our data, we suggest that the GA and AA genotype carriers might be a risk factor for T2DM as opposed to those carrying the GG genotype, which is in agreement with the hypothesis that leptin has a potent role in the development of insulin resistance among T2DM patients.

The role of leptin in the obesity-related hypertension pathogenesis appears to be a result of the circulatory system, renal activity \& modulation and sympathetic nervous system (SNS) activation [12,14] and can be prevented by adrenergic blockade drugs [11]. Elevated renal sympathetic nerve activity, which results in salt retention, volume expansion, and increased blood pressure, is one of the main outcomes of SNS activation in hypertension condition [44]. In addition to SNS activation, leptin induces the expression of the endothelin type A receptor in vascular smooth muscle cells and activates endothelin-1 production in vascular endothelial cells [46], and smooth muscle cell proliferation [47]. Previous study groups identified a positive association between systolic and diastolic blood pressure with the -2548G $>$ A LEP polymorphism. Among Tunisian obese (males), Ben Ali et al. [48] found that individuals with higher AA genotype have increased systolic and diastolic blood pressure against those carrying GG genotype. Brazilian obese patients have shown that the AA genotype had substantially lower systolic, diastolic, and mean arterial blood pressure [49]. However, our study showed no association between the -2548G $>$ A LEP polymorphism and hypertension. This difference in the relation between the $-2548 \mathrm{G}>\mathrm{A}$ $L E P$ polymorphism and blood pressure might be attributable to the difference in serum estrogen concentration between men and women, given that estrogen exerts various effects on the stimulation of nitric oxide production and prostaglandin as well as the inhibition of endothelin-1 release by vascular endothelial cells [50]. Hu et al. [51] reported that the relationship between increased serum leptin levels and blood pressure was heavily influenced by body-fat mass and distribution in a rural Chinese population. Another reason for this relation is hyperinsulinemia and insulin resistance and their association with hypertension. El-Gharbawy et al. [52] found a strong association between increased serum leptin levels and blood pressure in obese African women with hypertension, which disappeared after adjustment for another component of the insulin resistance syndrome.

One limitation of the present study was the smaller sample size. Another limitation is that we did not measure $\mathrm{HbA1c}$ and adiponectin as metabolic markers of obesity and obesity-related complications. Finally, this study also did not analyze leptin gene receptors together with the -2548G> A LEP polymorphism.

In this study, the differences in significance observed in terms of glycaemia, HOMA-IR and leptinemia and their association with the studied genetic variant was due to the size of sample used and gender (male female ratio). This is the reason that we observed significant associations when we consider the population overall but no significance was observed when they were sub grouped.

\section{Conclusions}

The current study found that the genotype distribution of the $-2548 \mathrm{G}>$ A variant of $L E P$ was associated with serum glucose and leptin levels in a set of Saudi obese individuals. Additionally, AA and GA genotypes and the -2548AA allele could be a potential risk factors for predisposing healthy subjects to T2DM. However, an extensive study with a larger sample size should be used to identify the real implication of correlations between the LEP polymorphism and diabetes mellitus, strengthening evidence for the LEP polymorphism as a genetic factor in diabetes mellitus risk. 
Author Contributions: Conceptualization: E.M.S., N.M.A.-D., L.S.B.D.; methodology: A.K.M., L.S.B.D. and E.M.S.; software: L.S.B.D.; A.K.M. and E.M.S.; samples investigation: L.S.B.D., K.M.S. and A.K.M.; manuscript writing: N.M.A.-D., A.K.M., E.M.S. and L.S.B.D.; manuscript review: N.M.A.-D. and K.M.S. All authors have read and agreed to the published version of the manuscript.

Funding: The authors are grateful to the Deanship of Scientific Research, King Saud University for funding this research through Vice Deanship of Scientific Research Chairs.

Institutional Review Board Statement: The present study was approved by the ethical committee at King Saud Medical City, Ministry of Health, Kingdom of Saudi Arabia on 17-1-2012 with reference number 11395.

Informed Consent Statement: Informed consent was obtained from all subjects involved in the study.

Data Availability Statement: The data that supports the findings of this study are all available in the manuscript.

Conflicts of Interest: Authors declare no conflict of interest.

\section{References}

1. Mensah, G.A.; Mokdad, A.H.; Ford, E.; Narayan, K.V.; Giles, W.H.; Vinicor, F.; Deedwania, P.C. Obesity, metabolic syndrome, and type 2 diabetes: Emerging epidemics and their cardiovascular implications. Cardiol. Clin. 2004, 22, 485-504. [CrossRef]

2. Jiang, S.Z.; Lu, W.; Zong, X.F.; Ruan, H.Y.; Liu, Y. Obesity and hypertension. Exp. Ther. Med. 2016, 12, 2395-2399. [CrossRef] [PubMed]

3. Zhou, B.; Perel, P.; Mensah, G.A.; Ezzati, M. Global epidemiology, health burden and effective interventions for elevated blood pressure and hypertension. Nat. Rev. Cardiol 2021, 18, 785-802. [CrossRef] [PubMed]

4. Lawes, C.M.; Vander Hoorn, S.; Rodgers, A. Global burden of blood-pressure-related disease, 2001. Lancet 2008, 371, 1513-1518. [CrossRef]

5. NCD Risk Factor Collaboration (NCD-RisC). Worldwide trends in body-mass index, underweight, overweight, and obesity from 1975 to 2016: A pooled analysis of 2416 population-based measurement studies in 128.9 million children, adolescents, and adults. Lancet 2017, 390, 2627-2642. [CrossRef]

6. NCD Risk Factor Collaboration (NCD-RisC). Worldwide trends in hypertension prevalence and progress in treatment and control from 1990 to 2019: A pooled analysis of 1201 population-representative studies with 104 million participants. Lancet 2021, 398, 957-980. [CrossRef]

7. Hall, J.E. The kidney, hypertension, and obesity. Hypertension 2003, 41, 625-633. [CrossRef]

8. Poirier, P.; Giles, T.D.; Bray, G.A.; Hong, Y.; Stern, J.S.; Pi-Sunyer, F.X.; Eckel, R.H.; American Heart Association; Obesity Committee of the Council on Nutrition, Physical Activity, and Metabolism. Obesity and cardiovascular disease: Pathophysiology, evaluation, and effect of weight loss: An update of the 1997 American Heart Association Scientific Statement on Obesity and Heart Disease from the Obesity Committee of the Council on Nutrition, Physical Activity, and Metabolism. Circulation 2006, 113, 898-918.

9. Barba, G.; Russo, O.; Siani, A.; Iacone, R.; Farinaro, E.; Gerardi, M.C.; Russo, P.; Della Valle, E.; Strazzullo, P. Plasma leptin and blood pressure in men: Graded association independent of body mass and fat pattern. Obes. Res. 2003, 11, 160-166. [CrossRef]

10. Mammes, O.; Betoulle, D.; Aubert, R.; Herbeth, B.; Siest, G.; Fumeron, F. Association of the G-2548A polymorphism in the 5' region of the LEP gene with overweight. Ann. Hum. Genet. 2000, 64, 391-394. [CrossRef]

11. Carlyle, M.; Jones, O.B.; Kuo, J.J.; Hall, J.E. Chronic cardiovascular and renal actions of leptin: Role of adrenergic activity. Hypertension 2002, 39, 496-501. [CrossRef] [PubMed]

12. Hall, J.E.; do Carmo, J.M.; da Silva, A.A.; Wang, Z.; Hall, M.E. Obesity-induced hypertension: Interaction of neurohumoral and renal mechanisms. Cir. Res. 2015, 116, 991-1006. [CrossRef] [PubMed]

13. Correia, M.L.; Haynes, W.G.; Rahmouni, K.; Morgan, D.A.; Sivitz, W.I.; Mark, A.L. The concept of selective leptin resistance. Evidence from Agouti yellow obese mice. Diabetes 2002, 51, 439-442. [PubMed]

14. Zhang, Y.; Proenca, R.; Maffei, M.; Barone, M.; Leopold, L.; Friedman, J.M. Positional cloning of the mouse obese gene and its human homologue. Nature 1994, 372, 425-432. [CrossRef] [PubMed]

15. Mammes, O.; Betoulle, D.; Aubert, R.; Giraud, V.; Tuzet, S.; Petiet, A.; Colas-Linhart, N.; Fumeron, F. Novel polymorphisms in the $5^{\prime}$ region of the LEP gene: Association with leptin levels and response to low-calorie diet in human obesity. Diabetes 1998, 47, 487-489. [CrossRef]

16. Shintani, M.; Ikegami, H.; Fujisawa, T.; Kawaguchi, Y.; Ohishi, M.; Katsuya, T.; Higaki, J.; Shimamoto, K.; Ogihara, T. Leptin Gene Polymorphism Is Associated with Hypertension Independent of Obesity. J. Clin. Endocrinol. Metab. 2002, 87, $2909-2912$. [CrossRef]

17. Hoffstedt, J.; Eriksson, P.; Mottagui-Tabar, S.; Arner, P. A polymorphism in the leptin promoter region (-2548G/A) influences gene expression and adipose tissue secretion of leptin. Horm. Metab. Res. 2002, 34, 355-359. [CrossRef]

18. Ali, S.B.; Kallel, A.; Ftouhi, B.; Sediri, Y.; Feki, M.; Slimane, H.; Jemaa, R.; Kaabachi, N. Association of G-2548A LEP polymorphism with plasma leptin levels in Tunisian obese patients. Clin. Biochem. 2009, 42, 584-588. 
19. Hinuy, H.M.; Hirata, M.H.; Forti, N.; Diament, J.; Sampaio, M.F.; Armaganijan, D.; Salazar, L.A.; Hirata, R.D. Leptin G-2548A promoter polymorphism is associated with increased plasma leptin and BMI in Brazilian women. Arq. Bras. Endocrinol. Metabol. 2008, 52, 611-616. [CrossRef]

20. Wang, T.N.; Huang, M.C.; Chang, W.T.; Ko, A.M.S.; Tsai, E.M.; Liu, C.S.; Lee, C.H.; Ko, Y.C. G-2548A polymorphism of the leptin gene is correlated with extreme obesity in Taiwanese aborigines. Obesity 2006, 14, 183-187. [CrossRef]

21. Ortega-Azorín, C.; Coltell, O.; Asensio, E.M.; Sorlí, J.V.; González, J.I.; Portolés, O.; Saiz, C.; Estruch, R.; Ramírez-Sabio, J.B.; Pérez-Fidalgo, A.; et al. Candidate gene and genome-wide association studies for circulating leptin levels reveal population and sex-specific associations in high cardiovascular risk Mediterranean subjects. Nutrients 2019, 11, 2751. [CrossRef]

22. Kargasheh, F.B.; Ansaripour, S.; Borumandnia, N.; Moradi, N.; Zandieh, Z.; Maleki, M.; Mokhtar, S.; Karimi, A.; Fatemi, F.; Kheirollahi, A.; et al. Association of leptin G2548A and leptin receptor Q223R polymorphisms and their serum levels with infertility and recurrent pregnancy loss in Iranian women with polycystic ovary syndrome. PLoS ONE 2021, 16, e0255920. [CrossRef]

23. World Health Organization. Physical Status: The Use and Interpretation of Anthropometry (1995) Report of WHO Expert Committee; WHO Technical Report Series, no. 854; WHO: Geneva, Switzerland, 1995; pp. 321-344.

24. Al-Daghri, N.; Alokail, M.; Al-Attas, O.; Sabico, S.; Kumar, S. Establishing abdominal height cut-offs and their association with conventional indices of obesity among Arab children and adolescents. Ann. Saudi Med. 2010, 30, 209-214. [CrossRef]

25. Chobanian, A.V.; Bakris, G.L.; Black, H.R.; Cushman, W.C.; Green, L.A.; Izzo, J.L., Jr.; Jones, D.W.; Materson, B.J.; Oparil, S.; Wright, J.T., Jr.; et al. The seventh report of the joint national committee on prevention, detection, evaluation, and treatment of high blood pressure. Hypertension 2003, 42, 1206-1252. [CrossRef]

26. American Diabetes Association. Standards of Medical Care in Diabetes, 2016. Diabetes Care 2016, 39, S4-S5. [CrossRef] [PubMed]

27. Friedewald, W.T.; Levy, R.I.; Fredrickson, D.S. Estimation of the concentration of low-density lipoprotein cholesterol in plasma, without use of the preparative ultracentrifuge. Clin. Chem. 1972, 18, 499-502. [CrossRef] [PubMed]

28. Matthews, D.R.; Hosker, J.P.; Rudenski, A.S.; Naylor, B.A.; Treacher, D.F.; Turner, R.C. Homeostasis model assessment: Insulin resistance and beta-cell function from fasting plasma glucose and insulin concentrations in man. Diabetologia 1985, 28, 412-419. [CrossRef]

29. Boumaiza, I.; Omezzine, A.; Rejeb, J.; Rebhi, L.; Ouedrani, A.; Ben Rejeb, N.; Nabli, N.; Ben Abdelaziz, A.; Bouslama, A. Relationship between leptin G2548A and leptin receptor Q223R gene polymorphisms and obesity and metabolic syndrome risk in Tunisian volunteers. Genet. Test. Mol. Biomark. 2012, 16, 726-733. [CrossRef]

30. Huuskonen, A.; Lappalainen, J.; Tanskanen, M.; Oksala, N.; Kyröläinen, H.; Atalay, M. Genetic variations of leptin and leptin receptor are associated with body composition changes in response to physical training. Cell Biochem. Funct. 2010, 28 , 306-312. [CrossRef] [PubMed]

31. Jiang, Y.; Wilk, J.B.; Borecki, I.; Williamson, S.; DeStefano, A.L.; Xu, G.; Liu, J.; Ellison, R.C.; Province, M.; Myers, R.H. Common variants in the $5^{\prime}$ region of the leptin gene are associated with body mass index in men from the National Heart, Lung, and Blood Institute Family Heart Study. Am. J. Hum. Genet. 2004, 75, 220-230. [CrossRef]

32. Şahın, S.; Rüstemoğlu, A.; Tekcan, A.; Taşliyurt, T.; Güven, H.; Yı̆̆ıt, S. Investigation of associations between obesity and LEP G2548A and LEPR 668A/G polymorphisms in a Turkish population. Dis. Markers 2013, 35, 673-677. [CrossRef]

33. Constantin, A.; Costache, G.; Sima, A.V.; Glavce, C.S.; Vladica, M.; Popov, D.L. Leptin G-2548A and leptin receptor Q223R gene polymorphisms are not associated with obesity in Romanian subjects. Biochem. Biophys. Res. Commun. 2010, 391, 282-286. [CrossRef] [PubMed]

34. Soskic, S.; Stokic, E.; Obradovic, M.; Sudar, E.; Tanic, N.; Kupusinac, A.; Djordjevic, J.; Isenovic, E.R. Association of leptin gene polymorphism G-2548A with metabolic and anthropometric parameters in obese patients in a Serbian population: Pilot study. Clin. Lipidol. 2014, 9, 505-513. [CrossRef]

35. Portolés, O.; Sorlí, J.V.; Francés, F.; Coltell, O.; González, J.I.; Sáiz, C.; Corella, D. Effect of genetic variation in the leptin gene promoter and the leptin receptor gene on obesity risk in a population-based case-control study in Spain. Eur. J. Epidemiol. 2006, 21, 605-612. [CrossRef]

36. Duarte, S.F.; Francischetti, E.A.; Genelhu, V.A.; Cabello, P.H.; Pimentel, M.M. LEPR p.Q223R, beta3-AR p.W64R and LEP c.-2548G>A gene variants in obese Brazilian subjects. Genet. Mol. Res. 2007, 6, 1035-1043.

37. Becer, E.; Kizilkanat, M.; Tinazli, M.; Serakinci, N. Association between leptin G-2548A gene polymorphism, plasma leptin levels and lipid profiles in Turkish Cypriot obese subjects. Turk. J. Biochem. 2016, 41, 1-8. [CrossRef]

38. Gong, D.W.; Bi, S.; Pratley, R.E.; Weintraub, B.D. Genomic structure and promoter analysis of the human obese gene. J. Biol. Chem. 1996, 271, 3971-3974. [CrossRef] [PubMed]

39. Mason, M.M.; He, Y.; Chen, H.; Quon, M.J.; Reitman, M. Regulation of leptin promoter function by Sp1, C/EBP, and a novel factor. Endocrinology 1998, 139, 1013-1022. [CrossRef]

40. Moreno-Aliaga, M.J.; Swarbrick, M.M.; Lorente-Cebrian, S.; Stanhope, K.L.; Havel, P.J.; Martinez, J.A. Sp1-mediated transcription is involved in the induction of leptin by insulin-stimulated glucose metabolism. J. Mol. Endocrinol. 2007, 38, 537-546. [CrossRef]

41. Yiannakouris, N.; Melistas, L.; Yannakoulia, M. The -2548G/A polymorphism in the human leptin gene promoter region is associated with plasma free leptin levels; interaction with adiposity and gender in healthy subjects. Hormones 2003, 2, 229-236. [CrossRef] 
42. Han, H.R.; Ryu, H.J.; Cha, H.S.; Go, M.J.; Ahn, Y.; Koo, B.K.; Cho, Y.M.; Lee, H.K.; Cho, N.H.; Shin, C.; et al. Genetic variations in the leptin and leptin receptor genes are associated with type 2 diabetes mellitus and metabolic traits in the Korean female population. Clin. Genet. 2008, 74, 105-115. [CrossRef] [PubMed]

43. Vaškù, J.A.B.; Vaškù, A.; Dostálová, Z.; Bienert, P. Association of leptin genetic polymorphism -2548G/A with gestational diabetes mellitus. Genes Nutr. 2006, 1, 117-123. [CrossRef] [PubMed]

44. Bains, V.; Kaur, H.; Badaruddoza, B. Association analysis of polymorphisms in LEP (rs7799039 and rs2167270) and LEPR (rs1137101) gene towards the development of type 2 diabetes in North Indian Punjabi population. Gene 2020, $754,144846$. [CrossRef] [PubMed]

45. Liu, H.L.; Lin, Y.G.; Wu, J.; Sun, H.; Gong, Z.C.; Hu, P.C.; Yin, J.Y.; Zhang, W.; Wang, D.; Zhou, H.H.; et al. Impact of genetic polymorphisms of leptin and TNF- $\alpha$ on rosiglitazone response in Chinese patients with type 2 diabetes. Eur. J. Clin. Pharmacol. 2008, 64, 663-671. [CrossRef] [PubMed]

46. Antic, V.; Dulloo, A.; Montani, J.P. Multiple mechanisms involved in obesity-induced hypertension. Heart Lung Circ. 2003, 12, 84-93. [CrossRef] [PubMed]

47. Juan, C.C.; Chuang, T.Y.; Lien, C.C.; Lin, Y.J.; Huang, S.W.; Kwok, C.F.; Ho, L.T. Leptin increases endothelin type A receptor levels in vascular smooth muscle cells. Am. J. Physiol. Endocrinol. Metab. 2008, 294, 481-487. [CrossRef] [PubMed]

48. Ben Ali, S.; Kallel, A.; Ftouhi, B.; Sediri, Y.; Feki, M.; Slimane, H.; Jemaa, R.; Kaabachi, N. The-2548G/A LEP polymorphism is associated with blood pressure in Tunisian obese patients. Blood Press. 2008, 17, 278-283. [CrossRef] [PubMed]

49. Genelhu, V.A.; Celoria, B.M.; Pimentel, M.M.; Duarte, S.F.; Cabello, P.H.; Francischetti, E.A. Association of a common variant of the leptin gene with blood pressure in an obese Brazilian population. Am. J. Hypertens. 2009, 22, 577-580. [CrossRef]

50. Koh, K.K. Effects of estrogen on the vascular wall: Vasomotor function and inflammation. Cardiovasc. Res. 2002, 55, 714-726. [CrossRef]

51. Hu, F.B.; Chen, C.; Wang, B.; Stampfer, M.J.; Xu, X. Leptin concentrations in relation to overall adiposity, fat distribution, and blood pressure in rural Chinese population. Int. J. Obes. Relat. Metab. Disord. 2001, 25, 121-125. [CrossRef]

52. El-Gharbawy, A.H.; Kotchen, J.M.; Grim, C.E.; Kaldunski, M.; Hoffmann, R.G.; Pausova, Z.; Hamet, P.; Kotchen, T.A. Gender specific correlates of leptin with hypertension-related phenotypes African Americans. Am. J. Hypertens. 2002, 15, 989-993. [CrossRef] 